\title{
In vitro management of Sclerotium rolfsii Sacc. - The causal agent of stem rot of sesame (Sesamum indicum L.)
}

\author{
Shamim Shamsi ${ }^{1}$, Najmun Naher ${ }^{2}$ \\ ${ }^{1}$ Department of Botany, University of Dhaka, Dhaka, Bangladesh, ${ }^{2}$ Department of Botany, Life and Earth Science Group, National University,
} Gazipur, Bangladesh

\begin{abstract}
An investigation was carried out during the tenure of March-September 2014 in search of fungal diseases of sesame. Seeds of two varieties, namely, BARI Til 2 and local variety Assima were collected from Satkhira and Jamalpur districts. Seeds were sown at the experimental field plot of Botanic garden, Department of Botany, University of Dhaka. Three types of symptoms, namely, stem rot, leaf spot, and fruit rot were recorded on sesame before flowering up to harvesting. Aspergillus flavus, Aspergillus niger, Alternaria alternata, Fusarium sp., Lasiodiplodia theobromae (Botryodiplodia theobromae), Corynespora cassiicola, Curvularia lunata, Penicillium sp., and Sclerotium rolfsii were isolated from plant parts on PDA medium following tissue planting method at temperature $25-28^{\circ} \mathrm{C}$ and $\mathrm{pH} 6.0$. Five fungicides, viz. Homai (Carbendazim), CM-75 (Carbendazim + Mancozeb), Ridomil Gold (Mancozeb + Matalexil), Score (Difenoconazole), and Tilt 250 EC (Propiconazole) at 50, 100, and $200 \mathrm{ppm}$ concentration were used to control test pathogen S. rolfsii in vitro. Tilt 250 EC found most effective and completely inhibited the radial growth of test pathogen at all the concentrations used.
\end{abstract}

Keywords: Causal agent, Management, Sclerotium rolfsii, Sesame indicum, Stem rot

\section{INTRODUCTION}

Sesame (Sesamum indicum L.) or "Til" is a member of the family Pedaliaceae, one of the world's oldest spice and oilseed crops. It was originated in Africa and is considered to be one of the primeval oil seed plants brought into cultivation in various parts of the world (FAO, 2004). The major sesame cultivated areas are greater Faridpur, Barisal, Rangamati, Dinajpur, Pabna, Khulna, Dhaka, Mymensingh, and Comilla (Rahman, 1976). It occupies 96,000 ha of land and produces 49,000 tons of sesame (FAO, 2012). It can be cultivated both in kharif and rabi seasons. The main reason behind this lower yield is lack of high-yielding variety and poor management practices. The scarcity of edible oil both from plant and animal sources is an acute problem in Bangladesh and the same is increasing day by day (Talukdar, 1974, Fakir, 1980, and Bakr et al., 2007 and 2009). In 2012, the sesame cultivating area was 33.20 thousand hectares and production was 30 thousand tons (BBS, 2012). More precisely, the area under sesame cultivation was 90.82 thousand hectares in 1989, whereas it decreased to 35.67 thousand hectares in 2012 (Khaleque and Begum, 1991).

Sesame seeds are small, almost oval in shape and have a mild and delicious aroma and taste (Hansen, 2011) The chemical composition of sesame shows that the seed is an important source of oil (44-58\%), protein (18-25\%), carbohydrate $(13.5 \%)$, and ash (5\%). Sesame seed is approximately $50 \%$ oil (out of which $35 \%$ is monounsaturated fatty acids and $44 \%$ polyunsaturated fatty acids) and $45 \%$ meal (out of which $20 \%$ is protein). Recently, sesame has been assessed on high nutritional and anti-aging feature with high quality of vegetable oil. Its oil is highly resistant to oxidative deterioration by containing antioxidant lignin such as sesamin and sesamolin (El Khier, 2008 and Ghandi, 2009).

In Sicily and France, the seeds are eaten on bread (ficelle sesame, sesame thread). In Greece, the seeds are also used in cakes. Fast-food restaurants use buns with tops sprinkled with sesame seeds. About 75\% of Mexico's sesame crop is purchased by McDonald's for use in their sesame seed buns worldwide (Reuters, 1992).

Seed-borne diseases are most disastrous and they reduce seed vigor, market value, and weaken the plant at the initial stages of its growth. The health of sesame plant is affected by fungi by causing infections on roots, foliage, and seeds (Shamsi and Hosen, 2016, Hosen and Shamsi, 2018a, and Shamsi,

DOI: $10.30954 / 2319-5169.2 .2020 .1$

Submission: $15-06-2020$

Received: $25-06-2020$

Acceptence: 19-09-2020

Published: 20-12-2020

${ }^{\star}$ Corresponding author: Shamim Shamsi, Department of Botany, University of Dhaka, Dhaka, Bangladesh. E-mail: prof.shamsi@gmail.com 
2018b). Little work had been done on seed-borne mycoflora of sesame and its control using plant extracts, fungicides, and antagonist fungi (Rahman et al., 1994, Hosen and Shamsi, 2017 and 2019).

There is very little information available about seed-borne disease of sesame, epidemiological aspects like role of seed inoculum in the disease development under different weather conditions, and management strategies like use of new and effective seed dressing fungicides along with latest approach like biopriming using novel biocontrol agents.

Hence, the present study was undertaken with the following objectives: (i) To identify pathogenic mycoflora associated with sesame seed collected from different growing areas. (ii) To develop suitable disease management techniques and improved storage methods to get disease-free seeds.

\section{MATERIALS AND METHODS}

Seeds of BARI Til-2 were collected from Satkhira and local variety Assima from Jamalpur district, respectively. It is a non-hairy medium-sized plant with primary and secondary branches with high potential plant.

The experiment was conducted during the period from March to July 2014 to observe the fungal diseases of sesame. The experiment was conducted at the research field of Curzon Hall campus of Dhaka University, Bangladesh. The experiment was laid out in randomized block design with three replications. The size of the unit block was $2.5 \mathrm{~m} \times 1.5 \mathrm{~m}$. The distance between two blocks was $50 \mathrm{~cm}$ each.

The total amount of manures and fertilizers, namely, TSP, half of MP, boric acid, and sulfur was applied as basal dose at the time of land preparation. The rest amount of MP and total amount of urea was applied in two installments at 15 and 30 days after of sowing. The seeds of BARI Til-2 and local variety of sesame Assima were sown in rows.

Irrigation was provided the plots immediately after germination of seedlings. Thinning was done carefully for better growth of the germinated paints and it was done manually after 20 days of sowing. Weeding was done 2 times at 10 and 25 days after seed sowing followed by irrigation.

Disease samples were collected by random sampling during early to mature stage of sesame and pressed for further identification. Ten disease infected plant parts, namely, infected stem, capsules, and seed were taken from each blocks and checked for diseases.

The fungi were isolated from the samples following the tissue planting method on PDA medium. Isolated fungi were transferred to separate PDA plates and PDA slants for further studies and preservation.

Identification of the isolates was determined based on morphological characteristics observed under a compound microscope following the standard literatures. Percent frequency of the occurrence of the fungal isolates was calculated by adopting the following formula of Spurr and Wetly.

All the isolated fungi were tested for their pathogenic potentiality in vitro following Azad and Shamsi (2011). Sclerotium rolfsii was exclusively showed pathogenic to sesame stem.

Pathogenicity test was carried out under filed condition. Two varieties of sesame such as BARI Til-2 and Assima were used in this study. Mature plants of sesame were inoculated by standard stem inoculation method (Botha et al., 2009). Sclerotium rolfsii was isolated from disease infected stem of sesame plants and grown on potato dextrose agar (PDA) medium in Petri dish at $25 \pm 2^{\circ} \mathrm{C}$ temperature. After 5 days of incubation, the inoculum is ready for use. The stem of mature plants of sesame was slightly pricked with the help of sterilized needle $1 \mathrm{ft}$ above the ground level of the plant. A mycelial disc of $7 \mathrm{~mm}$ diameter was taken from 5-day-old young culture of test pathogen Sclerotium rolfsii and placed on selected parts of the stem which was covered with sterilized wet cotton and tied with paraffin wax film and left for the appearance of symptoms. The control plants were treated with $7 \mathrm{~mm}$ agar block (without inoculum) also covered with wet cotton and tied with paraffin wax film.

Five fungicides, namely, Homai (Carbendazim), CM-75 (Carbendazim+ Mancozeb), Ridomil Gold (Mancozeb+ Matalexil), Score (Difenoconazole), and Tilt 250 EC (Propiconazole) at 50, 100, and $200 \mathrm{ppm}$ concentration were used to control test pathogen $S$. rolfsii in vitro. Preparation of stock solution and methodology of in vitro control were followed by Chowdhury et al. (2015).

The experiment was conducted in the Laboratory of Mycology and Plant Pathology, Department of Botany, University of Dhaka.

\section{RESULTS AND DISCUSSION}

A total of nine fungal species were isolated from different infected parts of sesame plant. The isolated fungi were Aspergillus flavus Link, Aspergillus niger van Tieghem, Alternaria alternata (Fr.) Keissler, Fusarium Link, Lasiodiplodia theobromae (Pat.) Griffon and Maubl. (Botryodiplodia theobromae), Corynespora cassiicola (Berk. and M.A. Curtis) C.T. Wei., Curvularia lunata (Wakker) Boedijn, Penicillium sp. Link, and Sclerotium rolfsii Sacc. Aspergillus flavus was isolated from seeds of variety Assima. Frequency percentage of occurrence of the fungus was 33.33. Aspergillus niger was isolated from all plant parts of the both varieties examined. Frequency percentage of occurrence of the fungus was 40 and 33.33 in both the varieties. Alternaria alternata was isolated from stem and capsule of BARI Til-2. Frequency percentage of occurrence of the fungus was lowest (1). Similarly, Lasiodiplodia theobromae and C. cassiicola were isolated from stem of BARI Til-2. Frequency percentage of occurrence of the fungus was lowest (1). Curvularia lunata 
was isolated from all plant parts of the same variety. Frequency percentage of occurrence of the fungus was 1, 20, and 80 in stem, capsule, and seeds, respectively. A species of Fusarium was exclusively isolated from stem and frequency percentage of occurrence of the fungus was 13.33. A species of Penicillium was exclusively isolated from stem and frequency percentage of occurrence of the fungus was 80 . About 100\% Sclerotium rolfsii was exclusively recorded from stem of both varieties studied [Table 1].

All the fungi isolated from different parts of sesame were tested for their pathogenic potentiality in vitro following Azad and Shamsi (2011). Sclerotium rolfsii exclusively showed pathogenic to sesame stem [Plate 1].

Colonies of $S$. rolfsii are readily distinguished on plant material or artificial media by gross morphological characteristics. Rapidly growing, silky-white hyphae tend to aggregate into rhizomorphic cords. In culture, the whole area of a Petri plate is rapidly covered with mycelium, including aerial hyphae which may cover the lid of the plate. Sclerotia $(0.5-2.0 \mathrm{~mm}$ diameter) begin to develop after 4-7 days of mycelial growth. After 10 days small white mycelial knots quickly turned in deep brown or brownish black color. Mature sclerotia resemble mustard seed. Sclerotia forming on host and culture showed smooth texture.

Nasira et al. (2004) reported that Alternaria sp., Curvularia sp., Fusarium sp., Helminthosporium sp., Memnoniella sp., Penicillium sp., and Rhizopus sp. which have been found associated with sesame. They equally reported that Alternaria sp. is the most destructive pathogen of sesame, as it causes small brown spots on leaf ranging from 1 to $8 \mathrm{~mm}$ in diameter. Infection of seeds reduces viability of seeds. Alternaria sesami produces brown necrotic sports on leaves.

Fusarium wilt (Fusarium oxysporum), charcoal rot (M. phaseolin), leaf spot (A. sesami), powdery mildew, and phytophthora blight are the most common diseases of sesame (Kotle, 1985). Many authors reported the incidence of $A$. flavus in sesame seeds along with other fungi (Mbah et al., 200001). Other fungi, namely, Aspergillus niger, A. viridis, A. alba, Fusarium sp., Alternaria radicina, A. brassicicola, Drechslera sp., Curvularia sp., Cephalosporium sp., and Penicillium sp. have also been isolated from sesame seed (Altaf et al., 2004).

Mukerji and Bhasin (1986) reported Alternaria sesame (Kawamura) Mohanty and Behera, Cercospora sesami Zimm., C. sesamicola Mohanty, Choanephora cucurbitarum (Berk, et Rav.) Thaxt., Colletotrichum sp., Corticium rolfsii Sacc.[= Sclerotium rolfsii Sacc.], Corynespora cassiicola (Berk. and M.A. Curtis) C.T. Wei., Curvularia lunata (Wakker) Boedijn, Fusarium vasinfectum Atk., Leveillula taurica (Lev.) Arnaud, Macrophomina phaseolina (Tassi) Goid., Myrothecium roridum Tode ex Fr., Oidium cladosporium Chiddarwar, Pellicularia filamentosa (Pat.) Rogers, Phoma exigua Desm., Phyllosticta sesame Bohochik., Phytophthora parasitica Dast., Pseudocercospora sesami Purkayastha and Malik, Pythium aphanidermatum (Eds.) Fitz., Sclerotium rolfsii Sacc., Sphaeronaema sesami S. P. Sehgal and Daftrai, Sphaerotheca fuliginea (Schlecht.) Pollacci, Synchytrium sesami Sinha and Gupta, and S. sesamicola Lacy from India.

From India, Radha (2013) reported Alternaria sesami, Aspergillus niger, Aspergillus flavus, Fusarium sp., Colletotrichum sp., Macrophomina sp., Penicillium sp., Botrytis sp., and Mucor sp. from seeds of sesame variety Mohanty and Behera.

From Bangladesh, Bakr et al., (2007) reported stem rot and leaf spot disease of sesame caused by Macrophomina phaseolina and Cercospora sesame, respectively. Hosen and Shamsi (2018a) also reported a total of nine species of fungi, namely, Aspergillus flavus, A. fumigatus, A. niger, Curvularia lunata, Fusarium merismoides, Mucor sp., Penicillium sp., Rhizopus stolonifer, and Trichoderma viride were isolated from the selected sesame seeds BARI Til- 3 and BARI Til-4. Among these fungi, Aspergillus spp. was predominant in both varieties of sesame. BARI Til-4 showed highest fungal incidence and BARI Til-3 showed lowest fungal incidence. BARI Til-3 showed highest seed germination while BARI Til-4 showed lowest seed germination.

Sesame (Sesamum indicum L.) attacked by nine diseases (among which stem rot and Cercospora leaf spot caused by Cercospora sesami and stem rot caused by Macrophomina

Table 1: Frequency \% of fungi associated with different parts of two varieties of sesame

\begin{tabular}{lcccc}
\hline Name of fungi & \multicolumn{2}{c}{ Plant parts } & Varieties \\
\cline { 2 - 4 } & Stem & Capsule & Seed & Assima \\
\hline Aspergillus flavus & - & - & 33.33 & Assima, BARI Til-2 \\
Aspergillus niger & 40 & 33.33 & 33.33 & BARI Til-2 \\
Alternaria alternata & 1 & 1 & - & BARI Til-2 \\
Lasiodiplodia theobromae & 1 & - & - & BARI Til-2 \\
Corynespora cassiicola & 1 & - & - & BARI Til-2 \\
Curvularia lunata & 1 & 20 & - & Assima \\
Fusarium sp. & 13.33 & - & 80 & BARI Til-2 \\
Penicillium sp. & - & - & - & Assima, BARI Til-2 \\
Sclerotium rolfsii & 100 & - &
\end{tabular}

${ }^{\prime}-{ }^{\prime}=$ No fungal growth 
phaseolina are the most destructive). Nine fungal species viz. Alternaria alternata, A. tenuis, A. flavus, A. niger,

Table 2: Percent inhibition of Sclerotium rolfsii by fungicides at different concentrations

\begin{tabular}{lccc}
\hline Name of Fungicide & \multicolumn{3}{c}{ Inhibition (\%) } \\
\cline { 2 - 4 } & $\mathbf{5 0} \mathbf{~ p p m}$ & $\mathbf{1 0 0} \mathbf{~ p p m}$ & $\mathbf{2 0 0} \mathbf{~ p p m}$ \\
\hline Homai (Carbendazim) & $0^{\mathrm{c}}$ & $0^{\mathrm{c}}$ & $0^{\mathrm{e}}$ \\
CM-75 (Carbendazim+ & $0^{\mathrm{c}}$ & $0^{\mathrm{c}}$ & $1.75^{\mathrm{d}}$ \\
$\begin{array}{l}\text { Mancozeb) } \\
\text { Ridomil Gold (Mancozeb+ }\end{array}$ & $0^{\mathrm{c}}$ & $0^{\mathrm{c}}$ & $5.53^{\mathrm{c}}$ \\
$\begin{array}{l}\text { Matalexil) } \\
\text { Score (Difenoconazole) }\end{array}$ & $64.15^{\mathrm{b}}$ & $78.59^{\mathrm{b}}$ & $84.70^{\mathrm{b}}$ \\
Tilt 250 EC (Propiconazole) & $79.96^{\mathrm{b}}$ & $84.48^{\mathrm{a}}$ & $100^{\mathrm{a}}$ \\
\hline Means with the same letter are not significantly different at 5\% level
\end{tabular}

F. moniliforme. C. cassiicola, M. phaseolina, Penicillium spp., and $R$. stolonifer isolated from sesame seed (Bakr et al., 2007). Two species of Corynespora and Fusarium merismoides Corda. also detected from sesame stem and seed, respectively (Shamsi and Sultana 2012; Shamsi and Hosen 2016).

Five fungicides, namely, Homai, CM-75, Ridomil Gold, Score, and Tilt $250 \mathrm{EC}$ at 50,100, and $200 \mathrm{ppm}$ concentration were used to control test pathogen $S$. rolfsii in vitro. Tilt 250 EC completely inhibited the radial growth of test pathogen at all the concentrations used. Score inhibited 64.15, 78.59, and $84.70 \%$ growth of the pathogen at 50,100 , and $200 \mathrm{ppm}$ concentrations, respectively. Ridomil Gold showed 5.53\% inhibition of the fungus at $200 \mathrm{ppm}$ concentration. CM-75 showed lowest growth inhibition of the fungus $1.75 \%$ at the same concentration. Homai did not show any effect on the pathogen [Table 2].

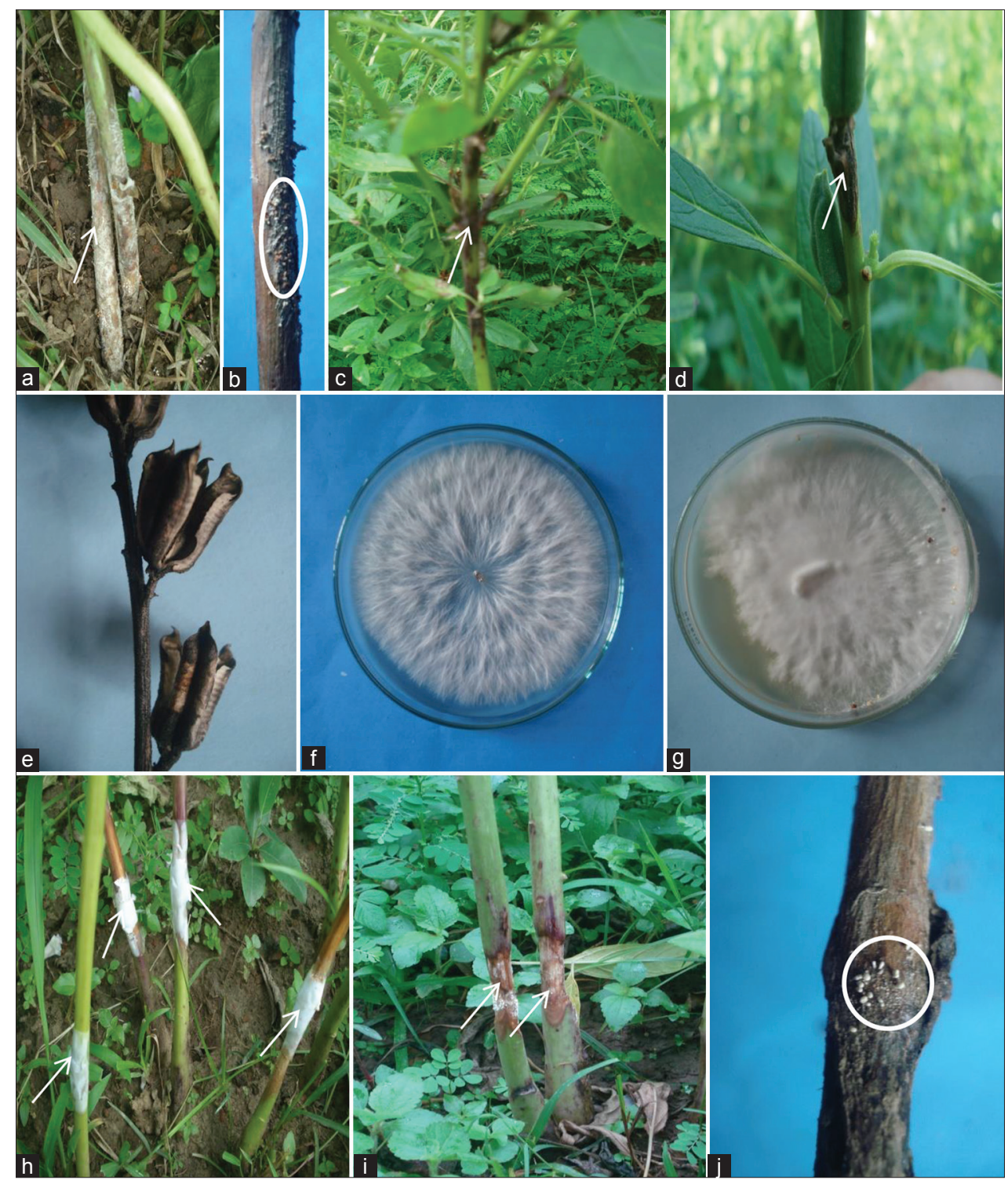

Plate 1: Photograph showing: Disease infected stem of sesame (a-d); disease infected capsule of sesame (e); colony of Sclerotium rolfsii (f and g); pathogenicity test on sesame stem (h); disease symptom produced after 7 days (i) and sclerotia develop on stem (j). 
After elucidative study, it was found that stem rot of sesame caused by Sclerotium rolfsii has not been reported in any relevant literature in Bangladesh (Talukdar, 1974, Bakr et al., 2007, 2009, and Shamsi, 2018).

Hence, stem rot of sesame caused by Sclerotium rolfsii is reported here as a new record from Bangladesh. Moreover, selected fungicides also $1^{\text {st }}$ time applied on the aforesaid pathogen. This is new addition to the field of mycology and plant pathology.

\section{CONCLUSION}

In Bangladesh, it is the second largest source of edible oil next to mustard. Most of the sesame seeds are used for oil extraction and the rest are used for edible purposes. Sesame seed is a common ingredient in various cuisines. It is used whole in cooking for its rich, nutty flavor. Sesame seeds are sometimes added to breads, including bagels and the tops of hamburger buns. Sesame seeds may be baked into crackers, often in the form of sticks. The health of sesame plant is affected by fungi by causing infections on roots, foliage, and seeds. Seed-borne diseases are most disastrous and they reduce seed vigor, market value, and weaken the plant at the initial stages of its growth.

Present investigation is the first report of stem rot of sesame caused by $S$. rolfsii and in vitro control of the causal organism.

Finding of these researches will be helpful for designing a proper management of sesame.

\section{Financial Support and Sponsorship}

Nil.

\section{Conflicts of Interest}

The authors declare that there is no conflict of interest in this work.

\section{REFERENCES}

Altaf, N.S., Khan, A., Ahmed, M., Asghar, A., Ahmed, R.A., Shaheen, S., Zafar, M. and Saqib, M. 2004. Seed borne Mycoflora of sesame (Sesamum indicum L.) and their effect on germination and seedling. Pak. J. Biol. Sci., 7, 243-245.

Azad, R. and Shamsi, S. 2011. Identification and pathogenic potentiality of fungi associated with Huttuyania cordata Thunb. Dhaka Univ. J. Biol. Sci., 20, 131-138.

Bakr, M.A., Ahmed, H.U. and Mian, M.A.W. 2007. Research on Crop Disease Management at Bangladesh Agricultural University. Advances in Plant Pathological Research in Bangladesh. Plant Pathology Division, BARI, Gazipur, Bangladesh. p. 344.

Bakr, M.A., Hossain, M.A. and Karim, M.M. 2009. Gradient of Oil Seed Crop Disease Management, Fungal Associations and Mycotoxin Contamination. Advances in Oilseed Researches in Bangladesh. Oilseed Research Centre BARI, Gazipur, Bangladesh. p. 180.

Barnett, H.L. and Hunter, B. 2000. Illustrated Genera of Imperfect Fungi. $4^{\text {th }}$ ed. Burgess Pub. Co., Minneapolis. p. 185.
BBS. 2012. Statistical Yearbook of Bangladesh. 23 ${ }^{\text {rd }}$ ed., Vol. 317. Statistics Division, Ministry of Planning, Government of the People's Republic of Bangladesh, Dhaka. pp. 97-98.

Botha, C., McLaren, N.W. and Swart, W.J. 2009. Evaluation of greenhouse inoculation techniques used to screen for Sclerotinia stem rot resistance in soybeans. S. Afr. J. Plant Soil., 26, 48-50.

CAB. 1968. Plant Pathologist Pocket Book. $1^{\text {st }}$ ed. The Commonwealth Mycological Institute, England. p. 267.

Chowdhury, C., Bashar, M.A. and Shamsi, S. 2015. In vitro evaluation of fungicides and plant extracts against pathogenic fungi of two rice varieties. Bangladesh J. Bot., 24, 251-259.

Ellis, M.B. 1971. Dematiaceous Hyphomycetes. The Commonwealth Mycological Institute, England. p. 608.

Ellis, M.B. 1976. More Dematiaceous Hyphomycetes. The Commonwealth Mycological Institute, England. p. 507.

Fakir, G.A. 1980. An Annoted List of Seed Borne Diseases in Bangladesh. Agricultural Information Service, Dhaka. p. 17.

FAO. 2004. Agricultural data. In: Agricultural Statistics Databases. Organization of the United Nations, Food and Agriculture Organization, Rome, Italy. Available from: http://www.fao.org/ faostat/en/\#search/sesame $\% 20$ seed.

FAO. 2012. Agricultural Data. In: Agricultural Statistics Databases. Organization of the United Nations, Food and Agriculture Organization Rome, Italy. Available from: http://www.fao.org/ faostat/en/\#search/sesame\%20seed.

Gandhi, A.P. 2009. Simplified process for the production of sesame seed (Sesamum indicum L.) butter and its nutritional profile. Asian J. Food Agroind., 2, 24-27.

Hansen, R. 2011. Sesame Profile. Available from: http://www.agmrc. org/commoditiesproducts/grains_oilseeds/sesame_profile.cfm. [Last accessed on 11 Aug 2019].

Hosen, M.D. and Shamsi, S. 2017. In vitro evaluation of selected fungicides and plant extracts against seed borne fungi of sesame (Sesamum indicum L.). Bangladesh J. Sci. Res., 30, 91-95.

Hosen, M.D. and Shamsi, S. 2018a. Quality assessment of two varieties of sesame seeds in Bangladesh. Plant Environ. Dev., 7, 10-14.

Hosen, M.D. and Shamsi, S. 2019. In vitro antagonism of Trichoderma viride and Aspergillus spp. against a pathogenic seed borne fungus of sesame. Bangladesh Acad. Sci., 43, 17-23.

Khaleque, M.A. and Begum, D. 1991. Area and production of oilseed crops, 1988-90. In: Fifteen Years of Oilseed Research and Development in Bangladesh. AST/CIDA, 1990. p. 28.

Khier, E.L., Ishag, M.K.S. and Yagoub, A.E.A. 2008. Chemical composition and oil characteristics of sesame seed cultivars grown in Sudan. Res. J. Agric. Bio. Sci., 4, 761-766.

Kotle, S.J. 1985. Diseases of Annual Oil Seed Crops. Vol. 2. Rapeseed-Mustard and Sesame Diseases. CRC Press Inc., Roca, Raton Florida, USA.

Mbah, M.C. and Akueshi, C.O. 2000. Effect of seed borne Fungi Aspergillus flavus and Aspergillus niger on the germinability of sesame seeds. Niger. J. Hortic. Soc., 4, 57-64.

Mbah, M.C. and Akueshi, C.O. 2001. Some Physico chemical changes induced by Aspergillus flavus and Aspergillus niger on Sesamum indicum and Sesamum radiatum. J. Sci. Agric. Food Technol. Environ., 1, 65-69.

Mukerji, K.G. and Bhasin, J. 1986. Plant diseases of India. A source Book. Tatta McGrew-Hill Publishing Company Ltd., New Delhi. p. 468.

Nasira, A., Shahid, A.K., Mushtaq, A., Rehuna, A.R., Ashfaq, A., Shabnum, S., Zafar, M. and Saqib, M. 2004. Seed borne 
Mycoflora of Sesame (Sesamum indicum L.) and their effect on germination and seedling growth. Pak. J. Biol. Sci., 7, 243-245.

Radha, P.L. 2013. Studies on Seed Borne Fungal Diseases of Sesame with Special References of Alternaria sesami (Kawamura) Mohanty and Behera. M.Sc Thesis in Agriculture. Bijapur University of Agriculture, India. p. 50.

Rahman, I. 1976. Importance of Oilseeds in the Economy and Nutrition of Bangladesh. Proceeding $1^{\text {st }}$ National Workshop on Oilseeds and Pulses, 11-13 October, 1976. Bangladesh Agricultural Research Council, Dhaka.

Rahman, M.M., MauIa, M.G., Begum, S. and Hossain, M.A. 1994. Maximization of Yield of Sesame through Management Practices. Central Annual Research. BARI, Joydebpur, Gazipur. pp. 53-56.

Raper, K.B. and Thom, C. 1949. Manual of the Penicillia. Williams and Wilkins, Baltimore, MD, USA. p. 875.

Reuters. 1992. "McDonald's Now Exporting from Mexico". The Toledo Blade. Available from: http://www.reuters.com.

Shamim, S. 2018. Morphological and Molecular Detection of Fungi in Bangladesh. Trends in Biochemistry and Molecular Biology. Nova Science Publishers, New York. p. 419.

Shamim, S. 2018b. Morphological and Molecular Detection of
Fungi in Bangladesh Trends in Biochemistry and Molecular Biology. Ch. 14. Nova Science Publishers, New York. p. 419.

Shamsi, S. and Hosen, M.D. 2016. Fuarium merismoids Corda. a new record of anamorphic fungus for Bangladesh. Bangladesh Acad. Sci., 40, 207-209.

Shamsi, S. and Sultana, R. 2012. New records of two species of Corynespora on sesame (Sesamum indicum L.) from Bangladesh. Bangladesh J. Plant Pathol., 27, 75-76.

Spurr, H.W.J. and Wetly, R.E. 1972. Incidence of tobacco leaf microflora in relation to brown spot disease and fungicidal treatment. Phytopathology, 62, 916-920.

Talukder, M.J. 1974. Plant diseases in Bangladesh. Bangladesh J. Agric. Res., 1, 61-86.

Thom, C. and Raper, K.B. 1945. A Manual of the Aspergilli. Williams and Wilkins, Baltimore, MD, USA. p. 373.

How to cite this article: Shamsi, S., Naher, N. 2020. In vitro management of Sclerotium rolfsii Sacc. - The causal agent of stem rot of sesame (Sesamum indicum L.). Int. J. Bioinform. Biol. Sci. 8(2), 1-6. 